Part 1: Theories, Speculations, \& Reassessments 
NOISE IN AND AS MUSIC 


\title{
Black Square and Bottle Rack: noise and noises
}
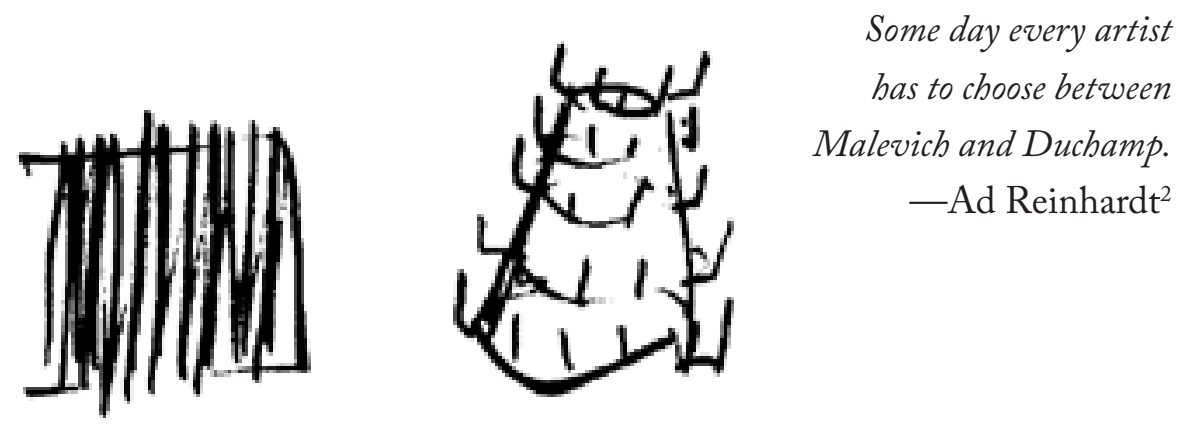

\author{
Peter Ablinger ${ }^{1}$
}

Noise and noises are not the same. In fact, they can be almost opposites. What the singular form refers to is the totality of white noise. What the plural refers to is the many individual objects, the event-related noises of everyday life. Obviously this distinction is very important to my own work and the use of "Rauschen" (white noise) within it, but what I want to argue here is that this distinction has already achieved a historical dimensionalthough it is one that seems not to be widely recognized.

As is so often the case, the visual arts discourse on the matter is decades ahead of the music discussion. The Ad Reinhardt quotation above is now 45 years old. To arrive in medias res, I want to equate Duchamp's readymades (e.g., the bottle rack) directly with the individual noises of everyday

\section{Additional editing by Henry Anderson}

2 The drawing is from my notebooks, circa 1997. Above the drawing I wrote (back-translating here from German): "Ad Reinhardt 1967: 'Basically, in the 20th century there is only the choice between Malewich and Duchamp." Another quotation of Reinhardt, as found online, says: "One must decide between Duchamp and Mondrian." [Editor's note: the version above is quoted in Phong Bui, "Mel Bochner with Phong Bui," The Brooklyn Rail, May 9, 2006, accessed July 19, 2013, http://www.brooklynrail.org/2006/05/art/ in-conversation-mel-bochner-with-phong-bui.] 
life, and to connect Malevich's most abstract paintings (like the black or the white square) to the idea of totality and the sum of all sounds-which, by definition, is white noise.

As I read Russolo and perceive Cage, their noises or rumori are about sounds as individual acoustic events, as the material, the building blocks, the modules (or found objects) that might constitute a composition. Thus, noises also represent the equivalent and complement of tones or instrumental sounds. In each of these respects, white noise is the opposite. White noise/ Rauschen $^{3}$ is not an individual in the sonic world, but its suspension. It is not an equivalent or a complement of tones, but rather it contains both the tones and the noises. It is the totality of all sounds and noises, their sum.

When John Cage, in "Lecture on Nothing," talked about Debussy, and about removal as a principle of composition, he appeared-at least for that moment-to be close to the idea of Rauschen: "Somebody asked Debussy how he wrote music. He said: I take all the tones there are, leave out the ones I don't want, and use all the others."

I don't know if Cage ever returned to that. After all, he had something against (acoustic) totalities, against Xenakis, against Free Jazz, and against situations in which the individuality of discrete sounds would be suspended in a mass or sum. And here we are now, exactly at this point of distinctionand in addition, in our hands we hold the key for opening up and acquiring its historical dimension.

The bottle rack motif, in my argument, does not refer to the readymade strategy itself (in the sense that the state of readiness is not further overworked during the process of becoming a piece of art) but more to the techniques of acknowledging noises as sonic individuals. Usually this means isolating, framing, recording, de-locating sounds (or objects), taking them

3 Significantly, the German word Rauschen has no plural. That is probably why I—also in English—tend to differentiate between the singular and the plural form: noise versus noises.

4 John Cage, "Lecture on Nothing," in Silence (Middletown: Wesleyan University Press, 1961), 117. 
out of their "natural" surroundings—in which they cannot be recognized as "individuals"-and repositioning them in an art or music context.

Kurt Schwitters, in 1920, wrote precisely about this aspect of removing something from its context: "the artist recognizes that in the world of manifestations that surround him, any particular only needs to be bordered and torn out of its context to result in a work of art." ${ }^{5}$

"Liberation of sounds" (Varèse, Cage) is necessarily connected to the techniques of isolation and de-contextualization. On a more philological or abstract level, however, I wonder whether the rhetoric of liberation is hiding something: the intended individualization—only subjects can be liberated!— is in truth an objectification.

Russolo, Varèse, Cage, musique concrète (Pierre Schaeffer), musique concrète instrumentale (Helmut Lachenmann), soundscapes, and field recordings ( $\mathrm{R}$. Murray Schafer)—all these and many more are thus clearly related to the bottle-rack aspect, or to (individual/isolated) noises.

It is the black square aspect of music, however, that is the less explored, the less exposed, and that must be treated carefully. I believe, though, that history itself has already delivered enough reference points to indicate the black square's relevance and true existence.

Cage's notion about Debussy has been our starting point for this, and Debussy himself could be observed more closely in that light. Josef Matthias Hauer is another early modernist dealing with the idea of totality. Yves Klein's Symphonie Monoton Silence relates to his monochrome paintings and therefore also to Malevich. Xenakis, whose interest in mass phenomena stands in opposition to Cage's individualization or liberation of sounds, provides another example. Certain qualities of extreme density in improvised music (Cecil Taylor) or in Noise Rock could also be discussed, and I am quite sure there are further examples, especially from the last 30 years.

5 In German: "Der Künstler erkennt, dass in der ihn umgebenden Welt von Erscheinungsformen irgend eine Einzelheit nur begrenzt und aus ihrem Zusammenhang gerissen zu werden braucht, damit ein Kunstwerk entsteht." 
Additionally, I present a short list of earlier examples of the use of white noise in different art pieces. Significantly, more artists in this list are media artists than musicians:

Peter Kubelka, Arnulf Rainer, 1960

Nam June Paik, Zen for Video, 1962

William Anastasi, Microphone, 1963

Howard Jones, Air 44, 1970

Marina Abramović, Sound Ambient White Noise, 1973

Wolf Kahlen, Drop Outs, 1993

I hope my notes so far have provided enough keywords to initiate discussion about the two streams of noise(s), and also to give some sense of the diversity (if not antagonism) of the two general concepts, each of which lead to different and often opposite artistic and compositional strategies.

But I would like to add one further thought related to my own research and to the "totality" aspect of white noise, because it is exactly this aspect that can generate effects of high "individualization." As soon as we shift our attention to its perceptual consequences, as soon as it is no longer about treating the sounds as individuals to be liberated, but about the real individuals—about us, the listeners-then white noise becomes a wonderful field for experience and exploration. In particular, the field of (individual) projection, interpretation, and acoustic illusion is well suited for examining the area of listening and the constructive role of our brain in that process.

What I learned from my own work-and especially its black square aspect-is that listening has nothing to do with an outer world that we receive passively. Rather, listening is a creative activity that forms both what we hear and how we hear. We are creating, therefore, nothing less than ourselves. 